\title{
Application of science and technology by the South African food and beverage industry
}

\author{
AUTHORS: \\ Lisa-Claire Ronquest-Ross ${ }^{1}$ (iD \\ Nick Vink2 iD \\ Gunnar 0. Sigge ${ }^{1}$ iD

\section{AFFILIATIONS:} \\ ${ }^{1}$ Department of Food Science, \\ Stellenbosch University, \\ Stellenbosch, South Africa \\ 2Department of Agricultural \\ Economics, Stellenbosch \\ University, Stellenbosch, \\ South Africa
}

\section{CORRESPONDENCE TO:} Lisa-Claire Ronquest-Ross

EMAIL:

lisaronquest@gmail.com

DATES:

Received: 16 Aug. 2017

Revised: 09 Jan. 2018

Accepted: 02 June 2018

Published: 11 Sep. 2018

\section{KEYWORDS:}

South Africa; food and beverage manufacturing industry; advances in science and technology; packaged food and beverages

\section{HOW TO CITE:}

Ronquest-Ross L-C, Vink N, Sigge GO. Application of science and technology by the South African food and beverage industry. S Afr J Sci. 2018;114(9/10), Art. \#4757, 11 pages. https://doi. org/10.17159/sajs.2018/4757

\section{ARTICLE INCLUDES: \\ $\times$ Supplementary material \\ $\times$ Data set}

FUNDING:

None

(C) 2018. The Author(s). Published under a Creative Commons Attribution Licence.
Significant shifts in the type of foods consumed by South Africans have taken place since 1994 and packaged food and beverage innovation has accelerated since then. Globally, advances in science and technology have benefitted food processing and food manufacturing technologies and systems. Significant capital investments have been made by the South African food and beverage manufacturing industry (SAFBMI). It is, however, not clear which technology areas have received investments and for what purposes. The objective of this study was thus to understand how the SAFBMI has invested in and applied science and technology since 1994. Data were sourced from food and beverage trade magazines, dating from 1986 to 2012. Trends over the past 30 years were analysed to determine the application of science and technology. The findings suggest that the dairy, soft drinks and bakery sectors have been most active. The main advances were to upgrade manufacturing facilities and build new plants to increase capacity, deliver new products and improve efficiencies and product quality and safety. Investments to improve thermal processing and packaging were also noted. We found evidence of the application of commercially available new preservation technologies and a low level of experimentation with non-commercial novel technologies by the SAFBMI. South Africa appears to be keeping pace with advances in food manufacturing in automation, process control and quality and food safety practices, material handling, and centralised distribution centres with warehouse management systems. Continued investment in food science and technology research will ensure that the growing consumer demand for packaged foods and beverages is met.

\section{Significance:}

- Although South Africa is keeping pace with science and technology advances in its food and beverage manufacturing operations, the need to continue to conduct and apply science and technology research, especially in novel processing, is highlighted.

\section{Introduction}

\section{The South African context}

South Africa changed after 27 April 1994 - changes that have impacted food consumption patterns as a result of shifts in food availability, accessibility and choices. Post-apartheid economic and transformation plans resulted in an increase in per capita income as well as the rise of a black middle class. ${ }^{1}$ However, population growth, together with urbanisation resulting from the removal of pass laws and disbanding of homelands, as well as an increase in women entering the labour market, have resulted in high unemployment levels. This unemployment rate is despite an increase in actual numbers of people employed since 1994, with youth unemployment remaining a real concern. ${ }^{1}$ There has also been significant growth of supermarkets, accounting for about $50-60 \%$ of retail sales. ${ }^{2}$ Access to water, sanitation and electricity have all advanced. ${ }^{1}$ Electricity allows access to refrigerators, ovens and microwaves, offering alternative food choices. The South African National Health and Nutrition Examination Survey-1 revealed that almost half (48\%) of South Africans reported that they had eaten out before, with $28.3 \%$ of South Africans eating out weekly. ${ }^{3}$

\section{The South African food and beverage manufacturing industry}

The phenomenon of globalisation is having a major impact on food systems around the world. Food systems are changing, resulting in greater availability and diversity of food. ${ }^{4}$ Over the last 50 years, practically all areas of food production and processing have been transformed. ${ }^{5}$ This increase has resulted in a consolidation of agricultural and food and beverage companies into large international corporations, which have developed global brands and marketing strategies with adaption to local tastes., ${ }^{5,6}$ These large corporations utilise global sourcing of supplies, centralisation of strategic assets and resources, as well as establishment of operations in several countries to succeed in a global market. 6,7

In 2012, there were over 1800 food manufacturing companies in South Africa. ${ }^{8}$ The South African food and beverage manufacturing industry (SAFBMI) is dominated by a few large, diversified, national and multinational food manufacturers, which have established market shares and control both production capacity and sales in most food categories. $^{9}$ The ten largest packaged-food companies in South Africa account for $52 \%$ of total packaged food sales. ${ }^{10}$ This proportion is greater than the global average, for which the top ten packaged food companies account for only $15.2 \%$ of sales. ${ }^{10}$ Furthermore, this figure is different from that of the soft drinks sector, where the top ten global and South African soft drink companies account for $52.3 \%$ and $79 \%$ of sales, respectively. ${ }^{10}$ Five of the top ten food manufacturing companies in South Africa in 2012 were South African, three of which had an international presence. ${ }^{8,11}$ The domination of a few large food and beverage manufacturers is a consequence of restricted licensing procedures and technical barriers to entry that limited the number of manufacturers under the apartheid government. ${ }^{12}$ However, more recently, new and smaller processors have started to play an important role and 
continue to change the competitive environment of food processing in South Africa despite their limited market share. ${ }^{9}$

Large multinational companies such as Nestlé (Switzerland), Unilever (United Kingdom/Netherlands), Lactalis/Parmalat Group (France/ Italy) and Mondelez (United States of America) operate their own manufacturing plants in South Africa, which produce and market their established brands. ${ }^{9}$ South Africa's key local players include companies such as Tiger Brands Ltd, Clover Ltd, Pioneer Foods Group Ltd, AVI Ltd, Premier Foods and Rainbow Chicken Limited. All of these food and beverage manufacturers depend on formal retail chains to sell their products. ${ }^{9}$ Many South African companies have formed associations with international companies, enabling access to the latest technology and expertise. Examples of these are Simba and Frito-Lay (United States of America) and Robertsons and Best Foods (United States of America). ${ }^{9}$

According to the Euromonitor 2012 report on the South African packaged food sector, this sector has grown from 2007 to 2012, in value by $57 \%$, from ZAR91 billion to ZAR143 billion, and in volume by $15 \%$, from 4515300 tonnes to 5202500 tonnes. ${ }^{13}$ Capital expenditure on new property, plants and equipment increased by $148 \%$, from ZAR4010 million in 2001 to ZAR9943 million in 2008..$^{14,15}$

\section{Food and beverage innovation in South Africa}

In recent years, there has been an increase in sales of almost all categories of packaged foods and beverages in South Africa. ${ }^{8,13}$ South African data derived from the Innova database indicates there has been a significant increase in product innovations and introductions in South Africa in the packaged food and beverage category since $2008 .{ }^{16}$ The categories with the highest number of product innovations and introductions were confectionery, sauces and seasonings, snacks, ready meals, soft drinks and hot drinks. ${ }^{16}$ There is a direct correlation between the development and implementation of new technologies and new, more desirable products on the shelf. ${ }^{17,18}$ The leading positioning behind these launches were convenience, health and choice. ${ }^{16}$ The increase in product innovation has translated into increased consumption of packaged food across all categories, with a decline of $13 \%$ only in canned/preserved food. ${ }^{19}$

\section{Food consumption changes since 1994}

Food consumption patterns have changed and will continue to change dramatically over the coming decades in South Africa..$^{19-21}$ Various foodrelated studies conducted over the past decades indicate that food consumption shifts in South Africa are towards a more Western-oriented diet with nutritional consequences contributing to increased obesity and other non-communicable diseases. ${ }^{22-24} \mathrm{~A}$ recent study by RonquestRoss et al. ${ }^{19}$ indicated that food consumption shifts are towards an overall increase in daily kilojoules consumed, a diet of sugar-sweetened beverages, increased proportion of processed and packaged food including edible vegetable oils, increased intake of animal-source foods, and added caloric sweeteners and away from vegetables (Figure 1). The largest shifts in food consumption were observed for soft drinks, sauces, dressings and condiments, sweet and savoury snacks, meat and fats and oils (Figure 1). These shifts in food consumption are concerning with respect to nutritional composition and public health. ${ }^{19}$ Convenience, health and wellness, and indulgence were the main consumer drivers for the increase in consumption of packaged foods since 1994. ${ }^{19}$

Locally and globally, fast food, bottled soft drink and multinational food companies are often implicated in the increase in non-communicable diseases. ${ }^{22,25}$ The Department of Health has therefore targeted the SAFBMI with regulations in an attempt to improve public health. These regulations include mandatory fortification of staple foods, maximum limit on trans-fat content in foodstuffs and reduction of salt in certain foodstuffs. Further regulations related to food composition and/ or labelling as well as consumer demand for healthier and affordable products will require advances in and/or the application of scientific and technological developments by the SAFBMI.

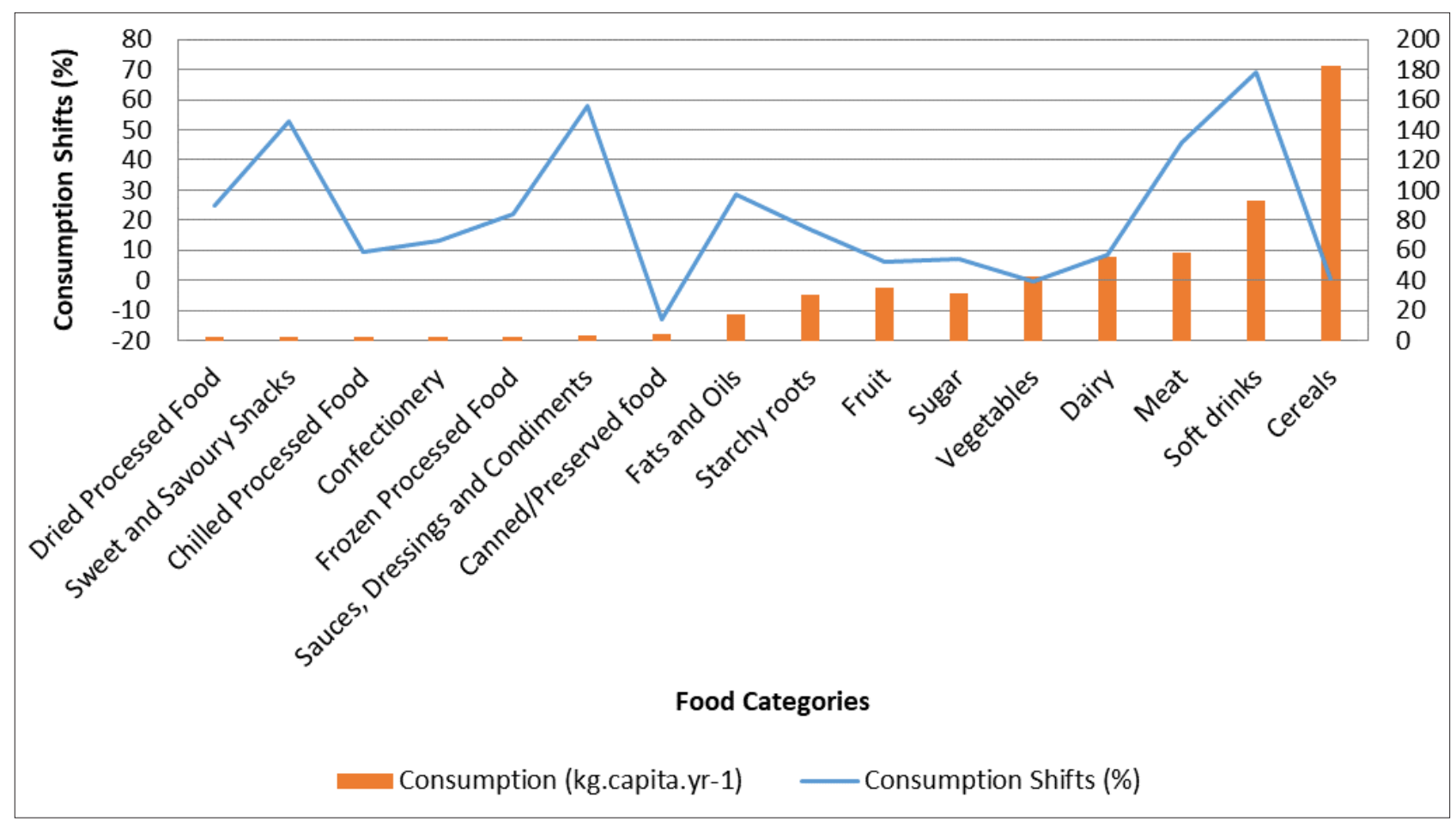

Source: Food and Agriculture Organization of the United Nations Statistics Division Food Balance Sheets and Euromonitor Packaged Food and Beverage Consumption. Taken from Ronquest-Ross et al. ${ }^{19}$

Figure 1: Per capita consumption and shifts in consumption of specific food categories in South Africa from 1994/1999 to 2009/2012. 


\section{Advances in food processing technologies and manufacturing}

Worldwide advances in food processing and packaging technologies Advancement in processing technologies through science and technology is one of the best tools to meet the challenges accompanying regulatory pressure to reduce the impact of food processing on the environment, meet the need for a stable and secure food supply and meet changing consumer demand for safer, better quality, 'fresher-tasting' or minimally processed foods. ${ }^{18,26}$ To meet these challenges, the food industry is devoting considerable resources and expertise to improving the way in which foods are produced, distributed, stored and retailed. ${ }^{26}$

Food preservation techniques can be classified as traditional if they are based on (1) the effects of temperature, (2) reduction of water activity or $\mathrm{pH}$ or (3) addition of preservatives. Food preservation techniques can be classified as emerging or novel preservation technologies when based on other processes. ${ }^{27}$ The main advantages of traditional techniques are lower operational costs, safety and the fact that they are well established and widely used ${ }^{27}$ Emerging or novel preservation technologies may be an important complement to existing traditional processes for certain foods, but their use is associated with certain risks which need to be evaluated by industries and regulatory authorities before commercialisation. ${ }^{27}$ Before successful development, implementation and adoption of a novel technology can take place, consumer acceptance, product quality, preservation efficacy and final product safety need to be assessed. ${ }^{28}$

There is extensive knowledge on thermal processing as a food preservation method and advances in technology enabled optimisation for maximum efficacy against microbial contamination with minimum deterioration of food quality. ${ }^{26}$ However, there is still a need for technologies that minimise the destructive influence of heat on food..$^{29}$ Because thermal energy has to be transmitted across the product itself to ensure effective microbial deactivation, even concepts like high-temperature-short-time processing are limited by the physical properties of the product. ${ }^{29}$ By 2012, there had been limited industrial applications of microwave heating, even though it is widely accepted by consumers for preparing foods and extensive research on this method has already been conducted. ${ }^{30,31}$ The process of ohmic heating involves passing alternating electrical current through a food product that serves as electrical resistance, causing it to heat up. ${ }^{31,32}$ There are a number of factors that affect the heating rate of foods with ohmic heating and therefore commercial applications are only for high-acid foods and these applications have been slow to realise. ${ }^{32}$

Novel non-thermal processing is being explored intensively to resolve many of the shortcomings related to thermal treatment as well as to meet consumer demands for minimal processing. Promising non-thermal pasteurisation technologies exist, such as high pressure, high-intensity pulsed electric field, pulsed light, oscillating magnetic field pulses and electron ionising radiation, which may be combined to yield the total bacterial reduction desired though the 'hurdle concept' of applying gentle steps to gradually reduce microbial counts. ${ }^{30,33} \mathrm{Apart}$ from high-pressure processing and pulsed electric field, by 2012, there had been limited commercial applications of other emerging non-thermal processing technologies because of technological barriers to standardise processes and validate product quality and safety. ${ }^{30,34-36}$

Packaging plays an important role in the food manufacturing process by making packaged foods more convenient, extending shelf life, allowing distribution across wide geographies while maintaining quality and food safety as well as providing containment, marketing and information,

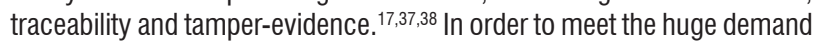
for processed food with a longer shelf life, various new methods of packaging are being used in the food-processing industry. ${ }^{37}$ Packaging can manage oxygen in the package through gas flushes, controlling internal atmosphere or modified atmosphere packaging and vacuum, and enabling clean-label products without preservatives. 18,39,40 'Smart packaging' is a term used to describe packaging that is either active or intelligent and provides information to the user through absorption or release of substances to or from the food or environment. ${ }^{40,41}$
Nanotechnology has been hailed as the industrial revolution of the 21st century and has been applied to food packaging to improve barrier properties, and provide active antimicrobial and antifungal surfaces, mechanical and heat-resistance properties, sensing and signalling microbiological and biochemical changes, traceability purposes and monitoring and repairing of tears in packaging. 38,40,42,43

The beverage industry has always been at the forefront of adopting innovative new packaging technologies. ${ }^{44}$ Examples of these are gasrelease packaging through a 'widget', flavour-release packaging like the Unistraw ${ }^{\mathrm{TM}}$ and nutrient-, probiotic- or enzyme-release packaging. ${ }^{44}$ Temperature control, such as in self-heating of plastic coffee cans or ready meals, thermochromic labelling to indicate the temperature of a beverage and improved tamper-proof packaging are other examples. ${ }^{38,44,45}$

Packaging technology advances the need to balance food protection with numerous issues such as energy and material costs, growing social and environmental concerns, strict regulations on pollutants and disposal of municipal solid waste. ${ }^{17,46}$ Reducing, reusing and recycling are the main initiatives in reducing the environmental impact of packaging. ${ }^{47}$ In terms of alternative packaging materials, biodegradable, renewable polymers are being extensively researched, with cellophane being the most common. ${ }^{46}$

\section{Advances in food manufacturing}

Technology can be used in all parts of the production process of foodprocessing plants ${ }^{48}$ and the competitive food manufacturer aims to adopt technology that will yield maximum efficiency and increased production throughputs at lower costs in their processing plants with better quality and enhanced food safety ${ }^{28,40,49}$. Automation in the food industry has delivered improved productivity, product quality and profitability benefits. ${ }^{40,49}$ Furthermore, advances in materials handling and process control have led to substantial improvements in product quality, efficiency and cost reduction..$^{50}$ Important techniques in achieving efficient materials handling include continuous handling techniques as opposed to manual handling, bulk handling, automation, the use of gravity (where possible), combining operations to eliminate intermediate steps, conveyor systems and using a systems approach from raw material to finished product to avoid bottlenecks or shortages. ${ }^{40,50}$

Advances in process control include the shift from controls reliant on operator skill to technology-based controls because of advances in microelectronics. ${ }^{50} \mathrm{~A}$ significant development in process control was the introduction of programmable logic controllers in the 1980s, which allow instructions to be programmed and executed automatically based on data received by sensors. ${ }^{50,51}$ The advances in microelectronics together with computer software technology developments have allowed fast data processing, giving manufacturers more sophisticated, efficient, affordable, interlinked and user-friendly process control systems. ${ }^{50,51}$ These systems are applied throughout the manufacturing process, from material resource planning and production planning and management to control of process conditions including product quality, energy consumption and product flow, collation and evaluation of process and product data, control of cleaning-in-place and packaging, warehousing, storage and distribution control..$^{50} \mathrm{~A}$ further significant development software is called Supervisory Control and Data Acquisition, which collects data from the programmable logic controller and displays it as animated graphics so that trends and historical data reports can be generated and adjustments can be made in real time. ${ }^{49,50}$ Robotics are another advancement, which came about as a result of advances in neural networks, vision systems, pressure-sensitive grippers and laser guidance systems. This technology is becoming more of a permanent feature in food manufacturing facilities and has been applied for picking and placing items into packaging as well as palletising of loads. ${ }^{40,50,52}$

In terms of warehousing and distribution, developments in software such as radio-frequency identification and automation of the complete purchase process - have enabled significant improvements. ${ }^{40,50}$ Modelling and simulation analysis in the 1980s and 1990s by retailers to reduce logistics costs and distribution times led to the development of fewer, larger regional distribution centres that could handle a range 
of products. ${ }^{50,53}$ The adoption of electronic data interchange allowed larger retailers to automatically replace products based on consumer purchases, effectively resulting in more frequent deliveries of small amounts to stores from regional distribution centres..$^{50}$

Advances in food safety and quality management by food manufacturers have been mainly driven by increased public and private standards. The control of food hazards (biological, chemical and physical) by food manufacturers has been through hazard analysis critical control points, which is a science-based approach to identify and establish control measures for specific hazards. ${ }^{32,40}$ Contaminants in products must be inspected and removed and technological advances such as electromagnetic spectrum X-ray or vision systems have enabled a non-destructive method with which to achieve this. ${ }^{40,49}$ Hyperspectral imaging is another inspection method for the analysis of the chemical composition of food products, allowing for examination of disease conditions, ripeness, hardness/tenderness, grading or contamination. ${ }^{49,54}$

Hygiene control systems should be applied throughout the food chain and, more specifically, to proper product and process design from a food manufacturer perspective. ${ }^{32}$ Equipment design for ease and effectiveness of cleaning is another aspect on which much attention has been focused, such as cleaning-in-place and material selection for equipment. ${ }^{40,50}$ Being able to trace a food product from production to distribution is critical because of the consumer focus on quality with more complex supply chains. This traceability can be achieved through barcodes or radio-frequency identification. ${ }^{40,49}$

A recent study of the United Kingdom food and beverage industry revealed that $55 \%$ of food and beverage manufacturers identified the primary technological innovation need as being related to improving product quality or delivering new products despite growing pressure on improving sustainability and resource efficiency. ${ }^{55}$ Emerging technology trends included efficiency, productivity, sustainability and salt and fat reduction. Furthermore, $60 \%$ of these food and beverage manufacturers felt that emerging trends such as efficiency, productivity, sustainability and salt and fat reduction would be instrumental in successfully delivering their strategic objectives. ${ }^{55}$ No such research could be found for South Africa.

There have been significant shifts in the foods consumed by South Africans, as packaged food and beverage innovation has accelerated since 1994.19 Globally, advances in science and technology regarding food processing have been made to meet consumer demand for minimally processed products and regulatory pressure to reduce the impact of food processing on the environment. Furthermore, advances in food manufacturing technologies and systems have also taken place to improve productivity, profitability and product quality. Significant capital investments have been made by the large and concentrated SAFBMI players in their local manufacturing facilities and supply chains. There are, however, no data to indicate in which technology areas these investments have been made and for what purpose. The objective of this study was therefore to understand how the SAFBMI (excluding alcohol) has invested and applied scientific and technological advances since 1994 to keep pace with the shifts in food consumption, consumer demands, competitive market dynamics and increasingly demanding regulations.

\section{Material and methods}

Food and beverage trade magazines were used as the source of scientific and technological advances that have been applied in the SAFBMI (excluding alcohol). These trade magazines were selected as they were the only relevant trade magazines available that spanned the time period under review, 1986 to 2012. They also report on activities in food and beverage processing and packaging technology in South Africa. South African Food Review (FR), a trade magazine for food and beverage manufacturers, informs readers about the introduction of new ingredients, equipment, products and packs. This trade magazine, published since 1986, provides objective commentary on local and international market trends and issues as well as relevant processing and packaging technologies. ${ }^{56}$ Food \& Beverage Reporter (F\&BR), a trade magazine focusing on strategy and technology for the industry, is the widest-circulating printed magazine for the food, beverage and packaging industries in southern Africa. It covers all sub-sectors in value-adding of food, such as milling, baking and processing, and has been published since $1995 .{ }^{57}$ Even though these trade magazines are not peer-reviewed or scientifically validated on the application of science and technology by the SAFBMI, they do represent the common knowledge available over this time period and hence formed the basis for this study.

A database was built by capturing articles written from 1986 to 2012 for FR and from 1995 to 2012 for F\&BR. Criteria for the selection of an article was that only feature articles (articles listed in the contents page) related to the application of science and technology by the SAFBMI, whose operations were in South Africa, were selected. The classification of the articles (referred to in the results and discussion section as 'activities') are an interpretation by the researcher based on the information shared in the article. The database was categorised according to the following: year, journal, volume, number, page, title, author, abstract, region, sector, company and activity type.

Activity type was classified as manufacturing, innovation or regulatory. A manufacturing activity was classified as an upgrade, new plant or new equipment. Innovation was split into the consumer driver behind the innovation and then into primary or secondary drivers. Regulatory activities were also classified and included legal requirements required by the South African government regarding the manufacture and sale of foodstuffs. Figure 2 further illustrates the categories of manufacturing activities. These were related to the rationale for the investment and type of process in which the activity was invested. Table 1 provides definitions and examples to explain the categories of activities. Graphs, charts and tables were then developed from the database using Microsoft Office Excel Pivots.

The data were analysed to determine trends in the application of science and technology. This study therefore provides an indicative, subjective review of the application of science and technology in the SAFBMI over the last three to four decades. It is not a scientifically validated or quantitative analysis, as trade magazines were used as the data source and not all applications of science and technology in the SAFBMI would have been published in trade magazines or as feature articles.

\section{Results and discussion}

The database contained over 370 entries for both FR and F\&BR. There has been a significant increase in activities in the SAFBMI since 1986 (Figure 3), including activities related to both food and beverage production facilities, e.g. upgrades, new equipment or new plants and product and/or packaging innovations. There was a marked shift in the number of activities in the late 1990s and early 2000s as South Africa emerged as a new democracy. This shift is highly correlated with gross domestic product per capita over this time period (Figure 3). ${ }^{58}$ Gross domestic product at purchasers' prices is the sum of gross value added by all resident producers in the economy, including any product taxes minus any subsidies not included in the value of the products. ${ }^{58}$

In terms of activity split over the assessment period, innovation activities (54\%) were more prevalent than production activities (46\%). This difference could be for a number of reasons, including the focus areas in which the selected trade magazines were publishing in that period. Upgrades and new plants were the majority of advances as they relate to production facilities rather than new equipment.

\section{Advances in science and technology}

Capacity was the primary rationale for making advances to production facilities for F\&BR data, with equal percentages for capacity, efficiency/ productivity and quality for FR data (Figure 4). This finding would be expected for a growing food and beverage industry such as that of South Africa over the time period measured. For instance, the South African packaged food sector grew in volume by $15 \%$ in 5 years from 2007 to $2012 .{ }^{13}$ 


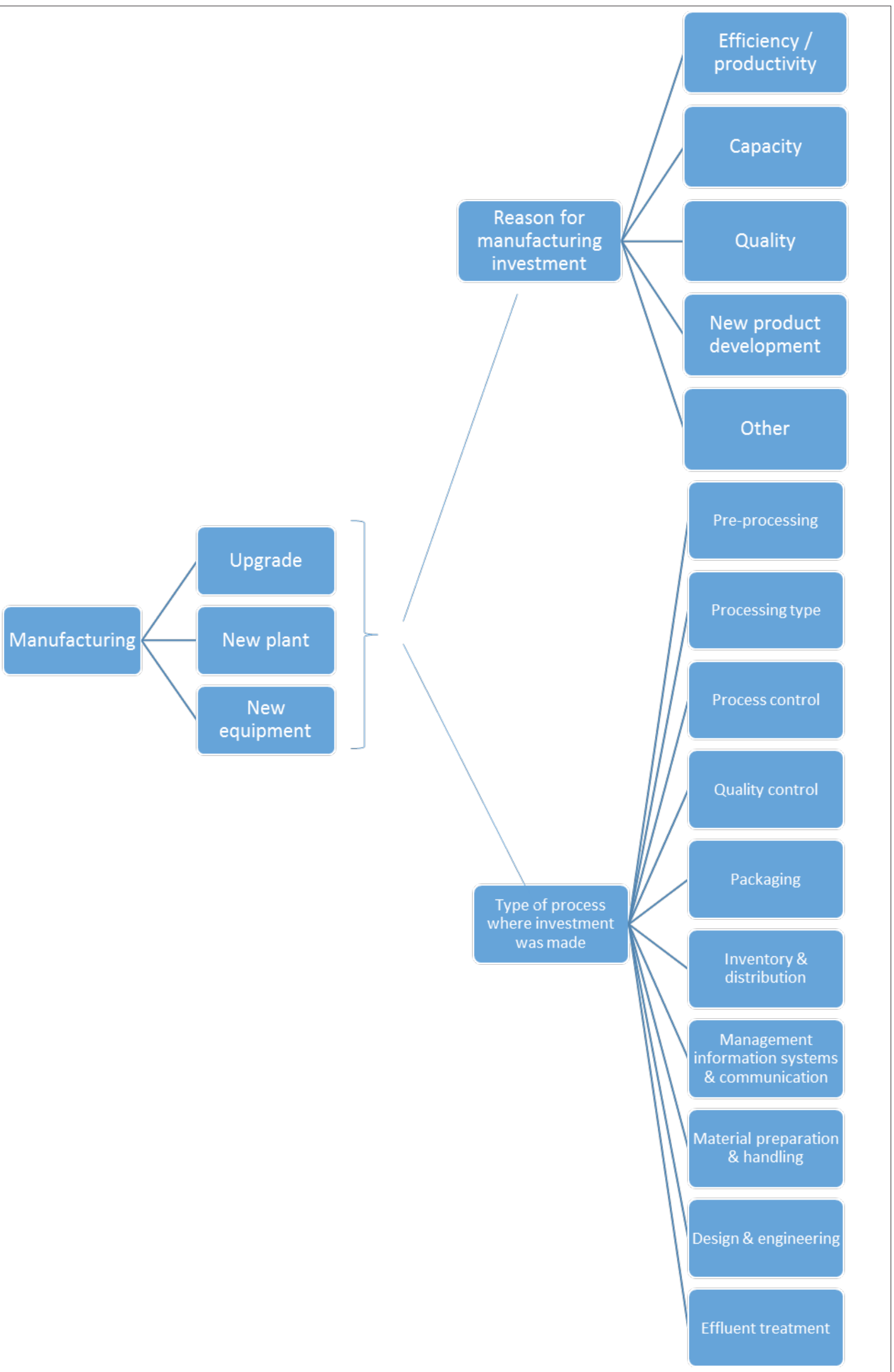

Figure 2: Further classification of manufacturing-related activities in the South African food and beverage manufacturing industry. 
Table 1: Definitions and examples of the classification of activities in the South African food and beverage manufacturing industry (adapted and extended from Fryer \& Versteeg ${ }^{30}$ and Baldwin et al. ${ }^{48}$ ) and general definitions

\begin{tabular}{|c|c|}
\hline Term & Definition \\
\hline Manufacturing & $\begin{array}{l}\text { The process of converting raw materials and packaging into finished goods. It includes the classification of upgrade, new plant } \\
\text { and new equipment for the purposes of efficiency/productivity, capacity, quality or other reasons. }\end{array}$ \\
\hline Upgrade & Investment to improve existing facilities. \\
\hline New plant & New building and manufacturing facilities. \\
\hline New equipment & New food and beverage processing equipment. \\
\hline Efficiency/productivity & Investments and upgrades to improve efficiency or increase productivity within the manufacturing facility. \\
\hline Capacity & Investments and upgrades to increase yield or output within the manufacturing facility. \\
\hline Quality & Investments and upgrades to improve product quality, e.g. reduction of defects, and to improve consistency or uniformity of product. \\
\hline Other & $\begin{array}{l}\text { Activities that did not fit into the criteria of efficiency/productivity, capacity or quality, e.g. replacing a building as a result of fire } \\
\text { destruction, an innovation centre, developing new capabilities and sustainability. }\end{array}$ \\
\hline Pre-processing & $\begin{array}{l}\text { Raw material quality assessments and enhancement before processing, e.g. animal stress reduction, bran removal before } \\
\text { milling wheat, electronic or ultrasonic grading, near-infrared analysis, colour assessment or sorting, electromechanical defect } \\
\text { sorting and rapid testing techniques. }\end{array}$ \\
\hline Processing type & $\begin{array}{l}\text { Food processing is the procedure that food undergoes to go from its raw state to a finished product, ready for storage and } \\
\text { shipping. }\end{array}$ \\
\hline Thermal & $\begin{array}{l}\text { Thermal processing is defined as the combination of temperature and time required to eliminate the desired number of } \\
\text { microorganisms from a food product, }{ }^{33} \text { e.g. aseptic processing, retortable, flexible pouches, infrared heating, ohmic heating } \\
\text { and microwave heating. }\end{array}$ \\
\hline Non-thermal & $\begin{array}{l}\text { Food is treated at ambient or refrigeration temperatures and heat generation during the process is not substantial, }{ }^{27} \text { e.g. } \\
\text { chemical antimicrobials, ultrasonic techniques, high pressure (cold pasteurisation), deep chilling and irradiation. }\end{array}$ \\
\hline $\begin{array}{r}\text { Separation, concentration and } \\
\text { water removal }\end{array}$ & $\begin{array}{l}\text { The removal or concentration of water for the purposes of preserving a product for an extended period, e.g. membrane, filter } \\
\text { technologies, centrifugation, ion exchange, vacuum microwave drying, water activity control and chromatographic separations. }\end{array}$ \\
\hline Additives and ingredients & Examples include bio-ingredients and microbial cells. \\
\hline Other & Specific food-processing technologies, e.g. drying, baking, milling, extrusion and coating. \\
\hline Process control & $\begin{array}{l}\text { Examples include automated sensor-based equipment for inspection/testing, automated statistical process control, machine } \\
\text { vision, barcoding, programmable logic controllers and computerised process control. }\end{array}$ \\
\hline Quality control & $\begin{array}{l}\text { Observation techniques and activities used to fulfil requirements for quality, including process testing, laboratory testing and } \\
\text { simulation, e.g. chromatography, monoclonal antibodies, DNA probes, rapid testing techniques and mathematical modelling of } \\
\text { quality or safety. }\end{array}$ \\
\hline Packaging & Various materials used to wrap or protect goods, including packaging assembly equipment. \\
\hline Advanced materials & Examples include laminates, active packaging and multi-layer packaging. \\
\hline Equipment & Examples include non-integrated or integrated electronically controlled machinery. \\
\hline Glass & Examples include glass bottles of different shapes and sizes. \\
\hline Metal & Examples include aluminium and tinplate cans. \\
\hline Plastic & Examples include PET, HDPE, LDPE and PP. \\
\hline Preservation & Examples include modified atmosphere. \\
\hline Other & $\begin{array}{l}\text { Mainly related to packaging artwork and design changes, e.g. graphics updates, limited edition packaging, label embossing or } \\
\text { decoration. }\end{array}$ \\
\hline Inventory and distribution & $\begin{array}{l}\text { Inventory is related to the management of raw materials, work-in-process and finished goods. Distribution is the storage and } \\
\text { delivery of products to the market place, e.g. barcoding and automated product handling. }\end{array}$ \\
\hline $\begin{array}{l}\text { Management information systems } \\
\text { and communication }\end{array}$ & $\begin{array}{l}\text { Examples include local area network, wide area network, inter-company computer networks, Internet marketing and promotion } \\
\text { and other Internet-related networks. }\end{array}$ \\
\hline Material preparation and handling & $\begin{array}{l}\text { Examples include integrated electronically controlled machinery, individual electronically controlled non-integrated machinery } \\
\text { and electronic detection of machinery failure. }\end{array}$ \\
\hline Design and engineering & $\begin{array}{l}\text { Examples include computer-aided design, computer-aided engineering, computer-aided manufacturing, computer-aided } \\
\text { simulation and prototypes and digital representation of computer-aided design output used in procurement. }\end{array}$ \\
\hline Effluent treatment & The treatment of waste water or air produced during the manufacturing process in order to reduce its environmental impact. \\
\hline Innovation & Involves new product or packaging and includes renovation or re-development of an existing range. \\
\hline Consumer driver - primary & $\begin{array}{l}\text { The main rationale or proposition behind a new product or packaging development from a consumer perspective. Drivers were } \\
\text { grouped into health and wellness, convenience, affordability, consumer preference, environment, food safety, product quality } \\
\text { and urbanisation. }\end{array}$ \\
\hline Consumer driver - secondary & $\begin{array}{l}\text { The supporting or secondary rationale or proposition behind a new product or packaging development from a consumer } \\
\text { perspective. Drivers were grouped into health and wellness, convenience, affordability, consumer preference, environment, } \\
\text { food safety, product quality and urbanisation. }\end{array}$ \\
\hline Regulatory & Related to all legal requirements of the South African government regarding the manufacture and sale of foodstuffs. \\
\hline \multicolumn{2}{|l|}{ General definitions } \\
\hline Soft drinks & $\begin{array}{l}\text { Cola carbonates, non-cola carbonates, fruit/vegetable juices, bottled water, concentrates, ready-to-drink teas and sports and } \\
\text { energy drinks. }\end{array}$ \\
\hline Dairy & Drinking milk products, cheese, yoghurt and sour milk and baby milk formula. \\
\hline Bakery & Baked goods (industrial and artisanal), biscuits and breakfast cereals. \\
\hline
\end{tabular}




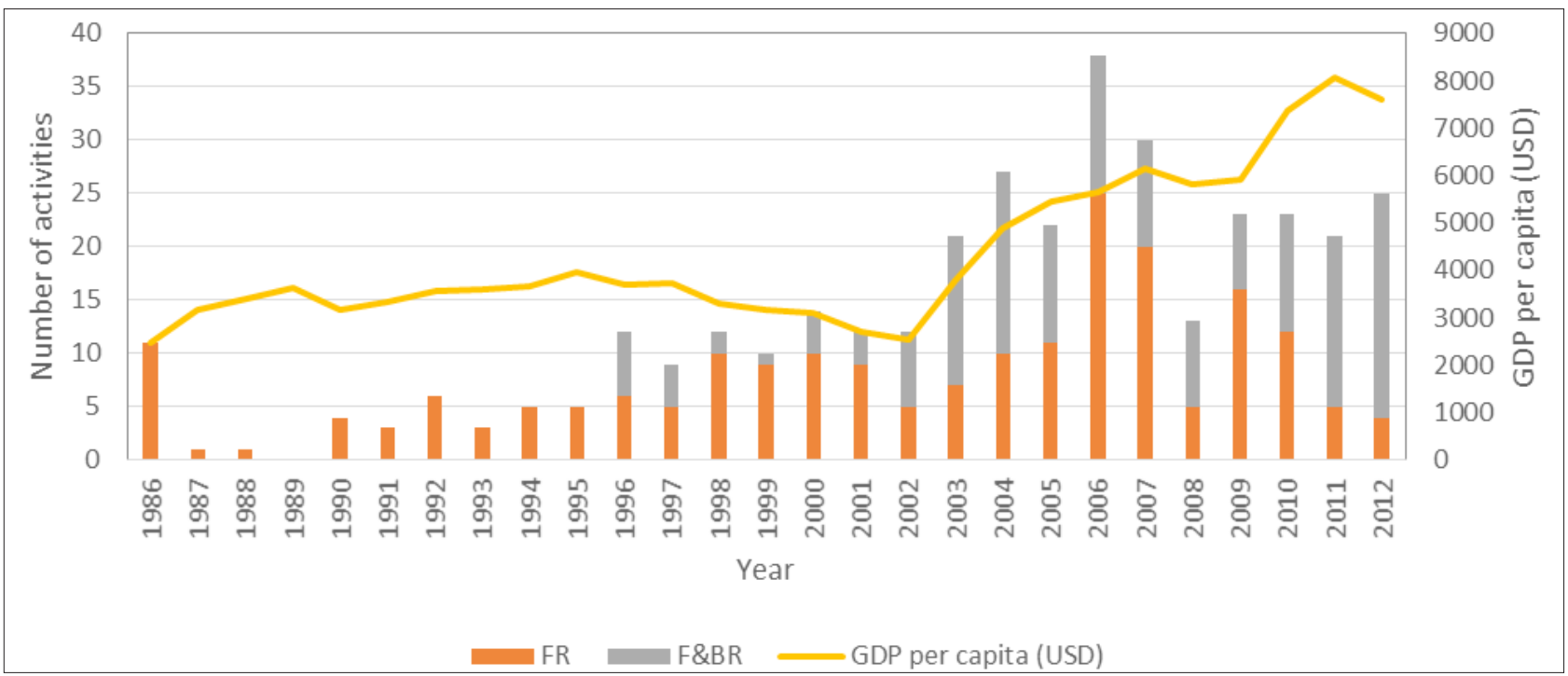

Figure 3: Number of activities recorded against gross domestic product (GDP) per capita obtained from South African Food Review (FR) from 1986 and Food \& Beverage Reporter (F\&BR) from 1996.

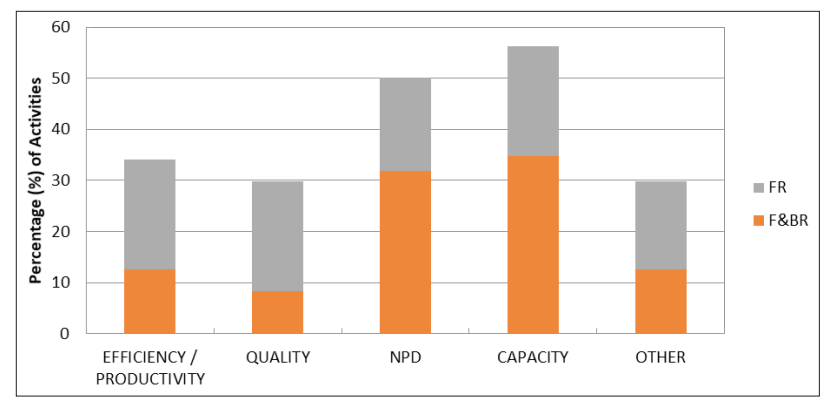

NPD, new product development

Figure 4: Rationale for production advances from Food \& Beverage Reporter (F\&BR) and South African Food Review (FR) data.

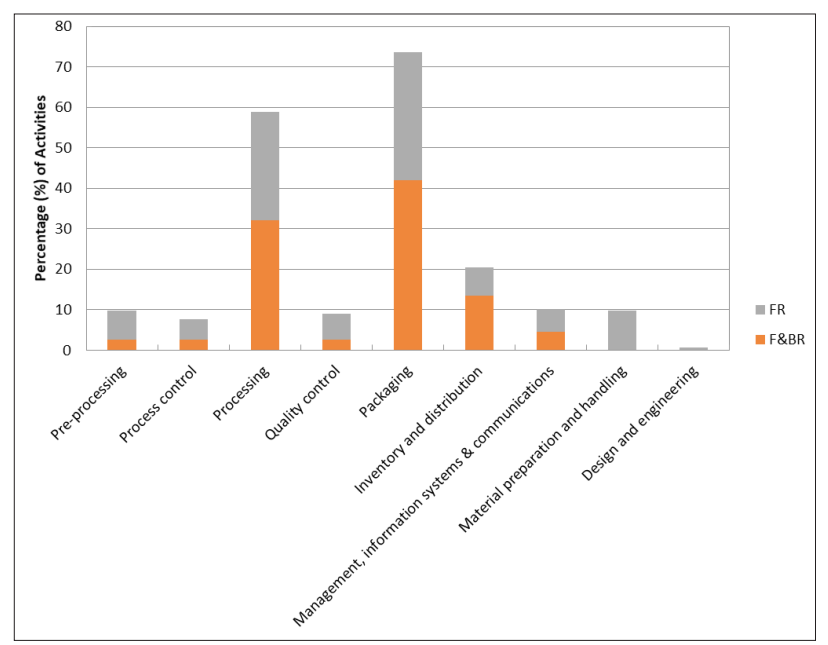

Figure 5: Focus areas of scientific and technological advances from Food \& Beverage Reporter (F\&BR) and South African Food Review (FR) data.

Packaging and processing were the main focus areas for scientific and technological advances and were consistent in both sets of data (Figure 5). Inventory and distribution and material preparation and handling were the second focus areas for the F\&BR and FR data, respectively (Figure 5). Relating to inventory and distribution, examples such as implementation of warehouse management systems, refrigeration and cold store upgrades and new, larger, more sustainable distribution centres were reported. Examples of material preparation and handling included automation, de-palletising and palletising equipment, conveyoring and mobile racking. Continued investment and advancement in science and technology is important to ensure products are safe and is necessary to continuously improve food safety management protocols. Examples of these food safety control measures noted in the study were detection and rejection of foreign objects through installation of metal detectors and colour/optical sorters, improved hygiene practices with the inclusion of cleaning-in-place and improved quality control practices with construction of in-house laboratories for product analysis and testing.

With a focus on scientific and technological advances in the processing arena, both FR and F\&BR data indicated that the top three investment areas were (1) thermal, (2) other and (3) separation, concentration and water removal (Figure 6). This result is not surprising as thermal processing is the most extensively researched and widely utilised processing technology. Advances in thermal processing were mainly by the dairy industry, which was consistent in both FR and F\&BR data. An example of advancement in thermal preservation is extended shelf life applied in the dairy industry since 2005. Extended shelf life involves fresh milk that has been treated in a specific manner, mostly by rapid heat/cool steam-infusion and mechanically via microfiltration or centrifugal separation, to reduce microbial count and pasteurise after being packaged under super-hygienic conditions. ${ }^{59}$ The infusion heating process is designed to kill heat-resistant psychotrophic aerobic spores, yielding a milk taste similar to that of pasteurised milk, with an extended shelf life under refrigerated conditions. ${ }^{59}$ Other processing activities were mainly related to the milling and baking industry with improved milling, baking, coating technology, breakfast cereals and cereal bars. Finally, for separation, concentration and water removal activities, FR data revealed that the dairy sector had the most activity in this type of processing, with F\&BR data indicating the dried processed food, fats and oils, and soft drinks (bottled water) sectors. An example is the use of osmotic concentration in the dried fruit industry to produce intermediate moisture foods that have a texture in-between that of dried and glacé fruit. An example of technology advances in the area of additives and ingredients is the application of advanced enzyme technology that eliminates the need for a cold chain for part-baked products and allows for smaller, more frequent bakes that last longer as a result of moisture retention. No feature articles related to the research of novel (i.e. not commercially available) thermal or non-thermal processing applications by the SAFBMI were noted over the time period documented. This finding could be for a number of reasons, such as the particular focus of the trade magazine, intellectual property protection and inability to disclose this information, insufficient numbers of research institutes (both academic and governmental) conducting research on novel processing or lack of funding and/or technical capability available in South Africa. 


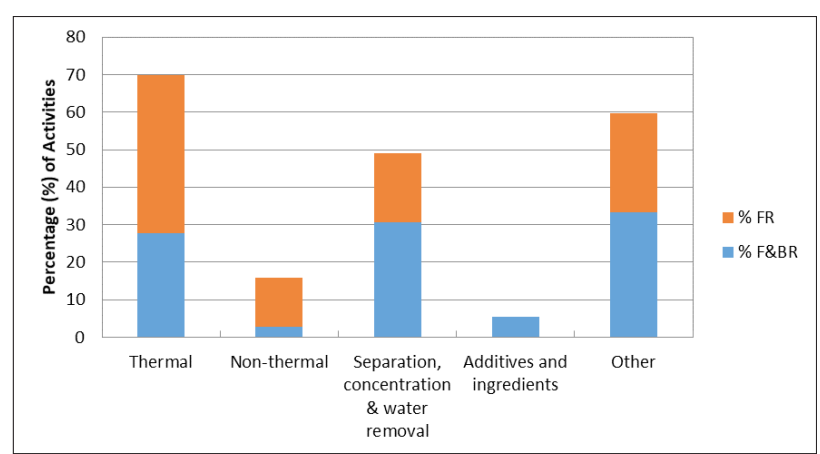

Figure 6: Scientific and technological advances by processing types from Food \& Beverage Reporter (F\&BR) and South African Food Review (FR) data.

From a packaging perspective, equipment, advanced materials and plastic were the main scientific and technological advances (Figure 7). Even though paper, glass, plastic and metals are South Africa's most utilised materials by volume, ${ }^{60}$ the evidence suggested that there has been much innovation and application of advanced materials over the last three to four decades. In terms of advanced materials, FR data indicated that the dairy and meat sectors were active in this area, while F\&BR data indicated the soft drink sector. A similar trend has been observed globally, with a shift away from rigid packaging to flexible packaging because of the benefits of being lightweight, improved barrier properties, ease of decoration, packaging format (variety and size) and dispensing options. $^{61}$ Furthermore, the innovative flavour-release packaging, Sipahh ${ }^{\circledR} 89$, which enables flavour 'beads' to dissolve in the beverage as the liquid passes through the straw, was launched in South Africa over this time period. There was one report indicating the application of modified atmosphere packaging utilised in the meat sector. In terms of equipment, the soft drink sector, in both sets of data, was most prolific. High-speed bottling lines, flow wrappers and multi-head weighers were some of the investments made in the equipment area. Soft drinks and dairy were the sectors most active in the plastic packaging category in both sets of data. No examples of the application of smart packaging were recorded.

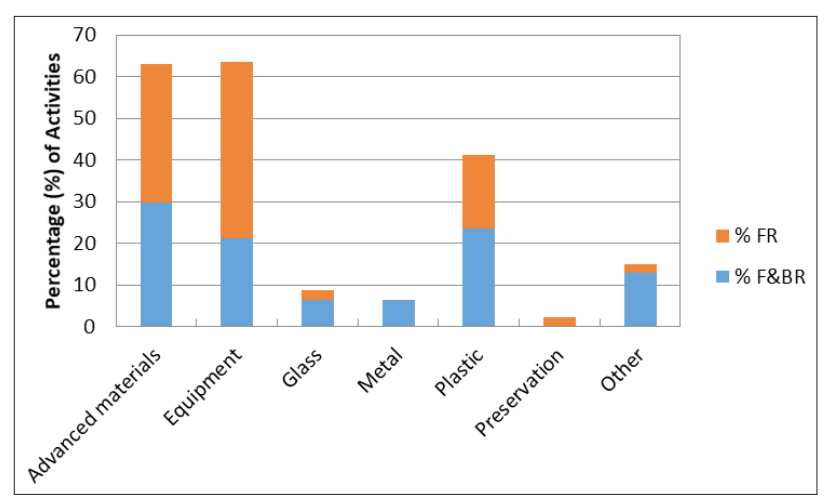

Figure 7: Scientific and technological advances by packaging types from Food \& Beverage Reporter (F\&BR) and South African Food Review (FR) data.

\section{Consumer drivers behind innovation activities}

Consumer drivers were derived from the rationale for product and/or packaging innovation. Both sets of data, across primary and secondary consumer drivers, indicated that the top three drivers of innovation were health and wellness, convenience and consumer preference (Figure 8). This finding was consistent with data from the Innova database (filtered for South Africa data), where convenience, health and choice were indicated as the main drivers. ${ }^{16}$

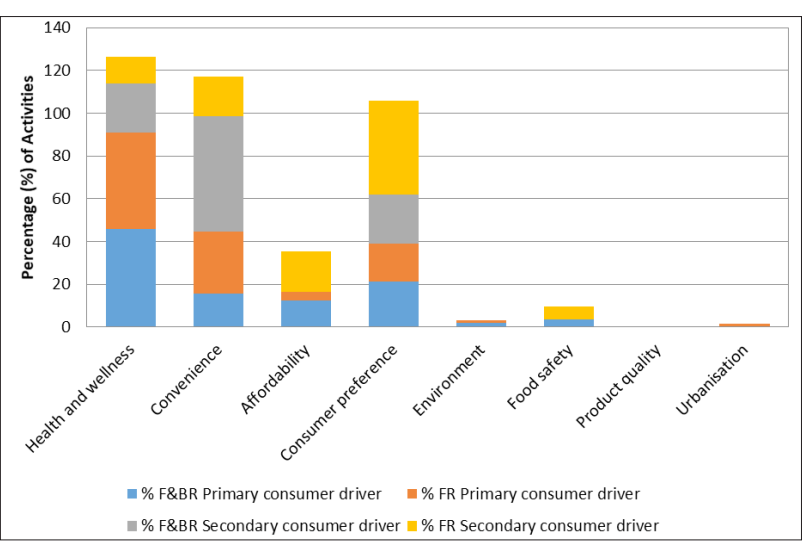

Figure 8: Primary and secondary consumer drivers for innovation from Food \& Beverage Reporter (F\&BR) and South African Food Review (FR) data.

\section{Food consumption changes and advances in science and technology}

In order to understand the link between food consumption changes in South Africa since 1994 and the application of science and technology and innovation activities, Figure 9 was generated. It is a combined data set of food consumption shifts taken from the Food and Agriculture Organization of the United Nations Statistics Division Food Balance Sheets and Euromonitor Passport from 1994/1999 to 2009/2012, ${ }^{19}$ plotted against the total number of activities (both production and innovation) by the SAFBMI. Soft drinks and dairy have been the most active sectors in terms of advances in science and technology and innovation since 1986 (Figure 9). It was also evident that there has been a large shift in the consumption of soft drinks over a similar period of time (Figure 9). In terms of data captured in the database for the soft drinks sector, innovation activities were nearly double that of production. Demand for healthier products such as bottled water, juice nectars, readyto-drink teas, low-calorie colas and non-cola carbonates have driven much of this innovation activity. ${ }^{62}$ Production activities implemented were related to upgrades, new plants and equipment to increase capacity and productivity. The soft drink category grew in volume by $14.9 \%$ in 5 years, from 4130 million litres in 2007 to 4745 million litres in $2012 .{ }^{62}$ To keep pace with that level of volume growth, it would make sense that upgrades were made to increase capacity and productivity.

Even though the dairy sector experienced a large increase in activities related to advances in science and technology and innovation, it did not experience large increases in dairy consumption overall. However, yoghurt and sour milk, which contributed a small percentage to the dairy category, experienced large increases in consumption (74\%)..$^{19}$ In terms of dairy, there was a balanced number of innovation- and production-related activities recorded in the database, with a focus on upgrades, new plants and equipment. The main reasons for the investment were related to increasing capabilities for new product development followed by productivity and capacity. The growing consumer demand for health and convenience drove new product developments in dairy over this time period. ${ }^{63}$ Spoonable yoghurt experienced growth of up to $10 \%$ in $2012^{64}$ and the majority of innovation activities recorded in this study were related to yoghurt innovation.

Bakery was the third-most active sector with overall consumption increases of $6.4 \%$ because of declines in consumption of packaged/industrial bread as consumers traded up to ready-to-eat breakfast cereals or down to maize meal, depending on their income situation (Figure 9). However, subcategories within the bakery sector, such as biscuits and breakfast cereals, saw large increases in consumption of $57 \%$ and $36 \%$, respectively, albeit off a small consumption base..$^{19}$ Furthermore, there was a balanced number of innovation- and production-related activities recorded in the database, with a focus mainly on upgrades and new plants. The main reasons for investment were related to capacity and quality improvements. Baked goods and biscuits increased in volume by $18.5 \%$ and $38.5 \%$, respectively, in 5 years, from 2007 to 2012, and hence the need for capacity investments. ${ }^{65,66}$ 


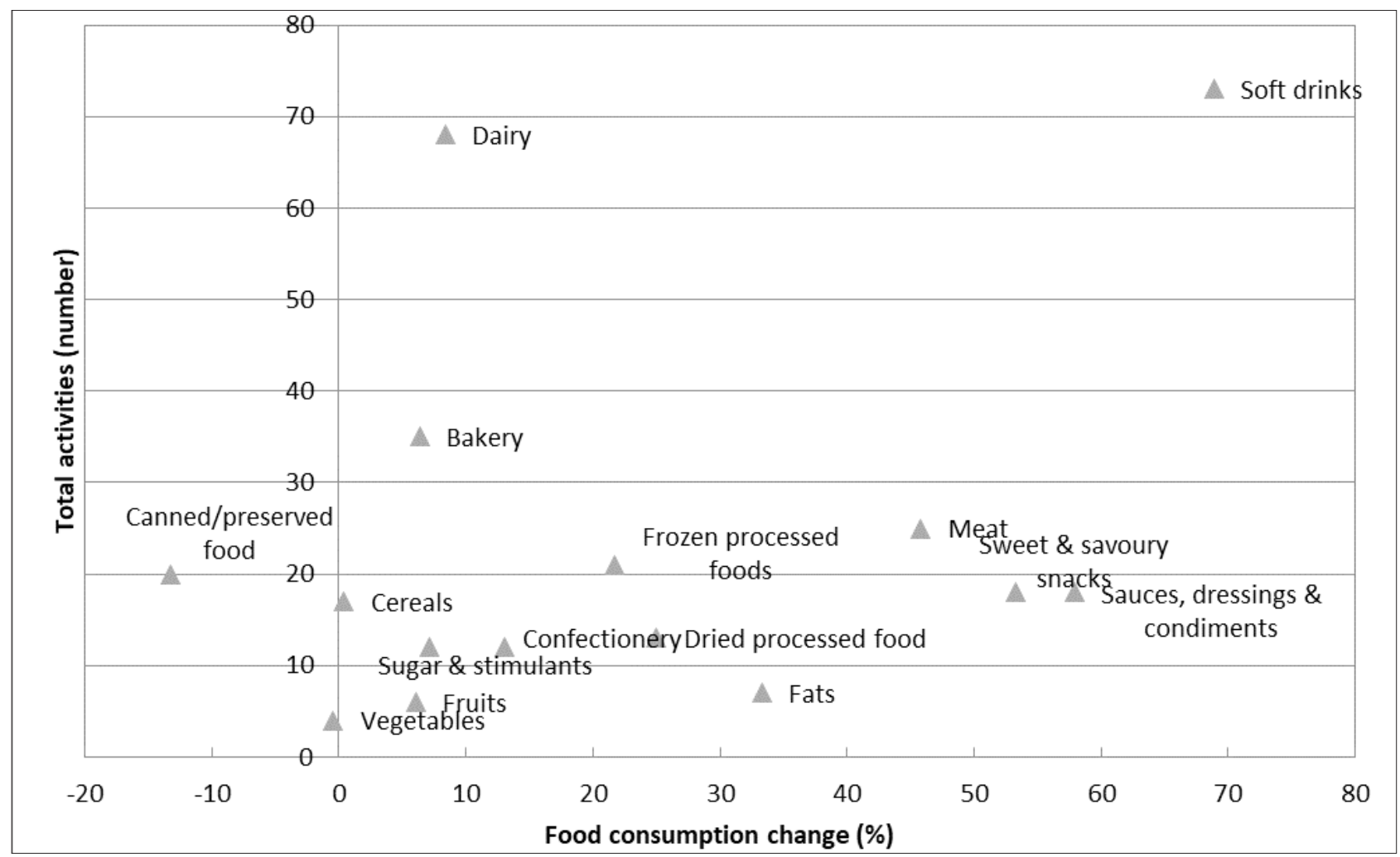

Figure 9: Number of activities by sector combined for both Food \& Beverage Reporter and South African Food Review data since 1986 compared with food consumption shifts from 1994/1999 to 2009/2012.

\section{Conclusion}

There have been dramatic and significant shifts in food consumption in South Africa since 1994, especially in the food categories soft drinks; sauces, dressings and condiments; sweet and savoury snacks; meat; and fats and oils. The SAFBMI responded by:

- Upgrading manufacturing facilities and building new plants to increase capacity, deliver new products and improve efficiencies and product quality and safety.

- Investing in processing, especially in the areas of thermal processing and other processing activities such as baking, milling and separation, concentration and water removal.

- Investing in the areas of packaging, including mainly equipment, advanced materials such as laminates and multilayer packaging and plastics.

- Innovating through new product and packaging launches to meet consumer drivers of health and nutrition, convenience and changing consumer preferences.

The packaged food and beverage industry became active relating to facility upgrades and building of new plants after 1994, with a sharp increase in product launches observed in the late 2000s..$^{16}$ The dairy, soft drinks and bakery sectors have been the most active. As far as advances in food preservation are concerned, there is evidence of the application of commercially available new preservation technologies such as thermal processing to extend the shelf life of milk and modified atmosphere packaging. Even though there have been advances in science and technology globally relating to novel processing, preservation and packaging, we found a low level of experimentation of these noncommercially available advances by the SAFBMI. From this research, South Africa would appear to be keeping pace with the advances in food manufacturing in the areas of automation, process and quality and food safety management, material handling as well as in the establishment of larger distribution centres with warehouse management systems, with the overall objective of improving production efficiencies.

It is important to recognise the limitation of this study, which is that it is based on common knowledge in the area of science and technology advances by SAFBMI available from trade magazines. We did not assess technical competence nor culture, which is fundamental to delivering innovative, safe and consistent quality products, efficiently.

In the future, investment and research in food science and technology by South African food and beverage manufacturers, research institutes and universities will continue to be necessary to achieve current and impending regulatory requirements as well as increasing consumer demand for packaged foods and beverages. Adoption of novel processing methods could yield product quality, safety, nutrition, productivity and capacity benefits.

\section{Acknowledgements}

We thank Johan Visser and Anee Sieberhagen at Nampak Research \& Development for providing access to their extensive library; Lu Ann Williams from Innova Market Insights for access to the Innova database; and Mars Africa for providing time and financial assistance.

\section{Authors' contributions}

L-C.R-R. was the project leader and responsible for data collection, analysis and validation and writing the manuscript; G.O.S. was the student supervisor and made editorial contributions; L-C.R-R., G.O.S. and N.V. were responsible for project design (conceptualisation and methodology).

\section{References}

1. The Presidency, Republic of South Africa. Twenty year review: South Africa: 1994-2014 [document on the Internet]. Pretoria: The Presidency; 2014 [cited 2014 0ct 12]. Available from: http://www.dpme.gov.za/news/ Documents/20\%20Year\%20Review.pdf 
2. Reardon T, Gulati A. The supermarket revolution in developing countries policies for "Competitiveness with Inclusiveness". International Food Policy Research Institute (IFPRI) Policy Brief 2. East Lansing, MI: Michigan State University; 2008

3. Shisana 0, Labadarios D, Rehle T, Simbayi L, Zuma K, Dhansay A, et al. South African National Health and Nutrition Examination Survey (SANHANES-1). Cape Town: HSRC Press; 2013.

4. Kennedy G, Nantel G, Shetty P. Globalisation of food systems in developing countries: A synthesis of country case studies. Food and Nutrition Paper 83. Rome: Food and Agriculture Organization of the United Nations; 2004

5. Chopra M, Galbraith S, Darnton-Hill I. A global response to a global problem: The epidemic of over nutrition. Bull World Health Organ. 2002;80(12):952958. http://dx.doi.org/10.1590/S0042-96862002001200009

6. Lang T. Food industrialisation and food power: Implications for food governance. Gatekeeper Series No. 114. London: International Institute for Environment and Development, Natural Resources Group and Sustainable Agriculture and Rural Livelihoods Programme; 2004.

7. Gardner G, Halweil B. Underfed and overfed: The global epidemic of malnutrition. Worldwatch Paper 150. Washington DC: Worldwatch Institute; 2000.

8. Igumbor EU, Sanders D, Puoane TR, Tsolekile L, Schwarz C, Purdy C, et al. "Big food," the consumer food environment, health, and the policy response in South Africa. PLoS Med. 2012;9(7), e1001253, 7 pages. https://doi. org/10.1371/journal.pmed.1001253

9. Ntloedibe M. South Africa's food processing sector offers opportunities for U.S. exporters. Pretoria: USDA Foreign Agricultural Service Global Agricultural Information Network; 2011.

10. Alexander E, Yach D, Mensah GA. Major multinational food and beverage companies and informal sector contributions to global food consumption: Implications for nutrition policy. Glob Health. 2011;7, Art. \#26, 8 pages. http://dx.doi.org/10.1186/1744-8603-7-26

11. Stuckler D, McKee M, Ebrahim S, Basu S. Manufacturing epidemics: The role of global producers in increased consumption of unhealthy commodities including processed foods, alcohol and tobacco. PLoS Med. 2012;9(6), e1001235, 8 pages. http://dx.doi.org/10.1371/journal.pmed.1001235

12. Mather $\mathrm{C}$. The growth challenges of small and medium enterprises (SMEs) in South Africa's food processing complex. Development Southern Africa. 2005;22(5):607-622. http://dx.doi.org/10.1080/03768350500364208

13. Euromonitor Passport packaged food in South Africa [database on the Internet]. c2012 [cited 2014 Oct 12]. Available from: http://www.portal. euromonitor.com/Portal/Default.aspx

14. Statistics South Africa. Large sample survey of the manufacturing industry 2001. Pretoria: Statistics South Africa; 2001.

15. Statistics South Africa. Manufacturing industry: Financial, 2008. Pretoria: Statistics South Africa; 2010.

16. Innova. Innova database search [database on the Internet]. 2014 [cited 2014 Jan 23]. Available from: http://new.innovadatabase.com/search/ searchresults.rails

17. Sonneveld K. What drives (food) packaging innovation? Packag Technol Sci. 2000;13:29-35. http://dx.doi.org/10.1002/(SICI)10991522(200001/02)13:1<29::AID-PTS489>3.0.C0;2-R

18. Andrews J. Technology: The core ingredient in 'natural' foods [webpage on the Internet]. Cape Town: FO0DStuff South Africa; 2016 [updated 2016 January 21; cited 2016 January 29]. Available from: http://www.foodstuffsa. co.za/news-stuff/food-science-and-technology-stuff/4363-technology-thecore-ingredient-in-natural-foods

19. Ronquest-Ross L-C, Vink N, Sigge GO. Food consumption changes in South Africa since 1994. S Afr J Sci. 2015;111(9/10), Art. \#2014-0354, 12 pages. https://doi.org/10.17159/sajs.2015/20140354

20. World Wildlife Fund. Agriculture: Facts and trends South Africa [document on the Internet]. c2012 [cited 2012 Dec 21]. Available from: http://awsassets. wwf.org.za/downloads/facts_brochure_mockup_04_b.pdf

21. Bureau for Food and Agricultural Policy (BFAP). The South African agricultural baseline [homepage on the Internet]. c2013 [cited 2013 Nov 04]. Available from: http://www.bfap.co.za/documents/baselines/BFAP_Baseline_2013
22. Kruger HS, Puoane T, Senekal M, Van der Merwe MT. Obesity in South Africa: Challenges for government and health professionals. Public Health Nutr. 2005;8(5):491-500. http://dx.doi.org/10.1079/PHN2005785

23. Popkin BM. Global nutrition dynamics: The world is shifting rapidly toward a diet linked with noncommunicable disease. Am J Clin Nutr. 2006;84(2):289 298. https://doi.org/10.1093/ajcn/84.2.289

24. Shisana O, Labadarios D, Rehle T, Simbayi L, Zuma K, Dhansay A, et al. South African National Health and Nutrition Examination Survey (SANHANES-1). Cape Town: HSRC Press; 2013.

25. Toepfl S, Mathys A, Heinz V, Knorr D. Review: Potential of high hydrostatic pressure and pulsed electric fields for energy efficient and environmentally friendly food processing. Food Rev Int. 2006;22(4):405-423. http://dx.doi. org/10.1080/87559120600865164

26. Lado BH, Yousef AE. Alternative food-preservation technologies: Efficacy and mechanisms. Microbes Infect. 2002;4(4):433-440. http://dx.doi. org/10.1016/S1276-4579(02)01557-5

27. Rodrigo D, Sampedro F, Silva A, Palop A, Martinez A. New food processing technologies as a paradigm of safety and quality. Brit Food J. 2010;112(5):467-475. http://dx.doi.org/10.1108/00070701011043727

28. Barbosa-Cánavos GV, Juliano P. Adaptation of classical processes to new technical developments and quality requirements. J Food Sci. 2004;69(5):240 250. http://dx.doi.org/10.1111/j.1365-2621.2004.tb10715.x

29. Heinz V, Alvarez I, Angersbacha A, Knorr D. Preservation of liquid foods by high intensity pulsed electric fields - basic concepts for process design. Trends Food Sci Tech. 2002;12(3-4):103-111. http://dx.doi.org/10.1016/ S0924-2244(01)00064-4

30. Fryer PJ, Versteeg C. Processing technology innovation in the food industry. Innov Manag Policy P. 2008;10(1):74-90. https://doi.org/10.5172/ impp.453.10.1.74

31. Floros JD, Newsome R, Fisher W, Barbosa-Cánovas GV, Chen H, Dunne $\mathrm{CP}$, et al. Feeding the world today and tomorrow: The importance of food science and technology, an IFT scientific review. Compr Rev Food Sci F. 2010;9(5):572-599. http://dx.doi.org/10.1111/j.1541-4337.2010.00127.x

32. Tucker G, Featherstone S. Essentials of thermal processing. Chichester: Wiley-Blackwell; 2011.

33. Zhang Q, Barbosa-Cánovas GV, Swanson BG. Engineering aspects of pulsed electric field pasteurisation. J Food Eng. 1995;25(2):261-281. http://dx.doi. org/10.1016/0260-8774(94)00030-D

34. Knorr D. New developments in industrial processing. Brussels: European Parliament Science and Technology Options Assessment (STOA); 2008. p. 23-26.

35. Koutchma T. Advances in ultraviolet light technology for non-thermal processing of liquid foods. Food Bioprocess Tech. 2009;2(2):138-155. http://dx.doi.org/10.1007/s11947-008-0178-3

36. Gayán E, Álavrez I, Condón S. Inactivation of bacterial spores by UV-C light. Innov Food Sci Emerg. 2013;19:140-145. http://dx.doi.org/10.1016/j. ifset.2013.04.007

37. Ansari IA, Datta K. An overview of sterilisation methods for packaging materials used in aseptic packaging systems. Food Bioprod Process. 2003;81(1):57-65. http://dx.doi.org/10.1205/096030803765208670

38. Brody AL, Bugusu B, Han JH, Sand CK, McHugh TH. Scientific status summary. J Food Sci. 2008;73(8):R107-R116. http://dx.doi.org/10.1111/ j.1750-3841.2008.00933.x

39. Martínez-Romero D, Guillén F, Castillo S, Valero D, Serrano M. Modified atmosphere packaging maintains quality of table grapes. J Food Sci. 2003;68(5):1838-1843. http://dx.doi.org/10.1111/j.1365-2621.2003. tb12339.x

40. Mahalik NP. Advances in packaging methods, processes and systems. Challenges. 2014;5(2):374-389. http://dx.doi.org/10.3390/challe5020374

41. Rijk R. Legislative issues relating to smart packaging. In: Kerry J, Butler P, editors. Smart packaging technologies for fast moving consumer goods. Chichester: John Wiley \& Sons; 2008. p. 305-320. https://doi. org/10.1002/9780470753699.ch17 
42. Sozer N, Kokini JL. Nanotechnology and its applications in the food sector. Trends Biotechnol. 2008;27(2):82-89. http://dx.doi.org/10.1016/j. tibtech.2008.10.010

43. Meetoo DD. Nanotechnology and the food sector: From the farm to the table. Emir J Food Agric. 2011;23(5):387-403.

44. O'Sullivan MG, Kerry JP. Smart packaging technologies for beverage products. In: Kerry J, Butler P, editors. Smart packaging technologies for fast moving consumer goods. Chichester: John Wiley \& Sons; 2008. p. 211-229. https://doi.org/10.1002/9780470753699.ch12

45. Steeman A. The self-cooling technology and the future - part 3 [webpage on the Internet]. c2012 [updated 2012 Dec 17; cited 2016 Jun 16]. Available from: https://bestinpackaging.com/2012/12/17/the-self-cooling-technologyand-the-future-part-3/

46. Marsh K, Bugusu B. Food packaging - roles, materials, and environmental issues. J Food Sci. 2007;72(3):R39-R55. http://dx.doi.org/10.1111/j.17503841.2007.00301.x

47. Sterling S. Field guide to sustainable packaging. Chicago, IL: Summit; 2007.

48. Baldwin J, Sabourin D, West D. Advanced technology in the Canadian food processing industry. Statistics Canada catalogue no. 88-518-XIE. Ottawa: Agriculture and Agri-Food Canada; 1999.

49. Sani MS, Aziz FA. Advanced manufacturing systems in food processing and packaging industry. Mater Sci Eng. 2013;46, Art. \#012042, 9 pages. http:// dx.doi.org/10.1088/1757-899X/46/1/012042

50. Fellows PJ. Food processing technology principles and practice. 3rd ed. Cambridge: Woodhead; 2009.

51. Leisemann Immel R. Programmable logic controller evolution [webpage on the Internet]. c2012 [updated 2012 Mar 19; cited 2016 Jun 11]. Available from: http://www.mbtmag.com/article/2012/03/programmable-logiccontroller-evolution

52. Alpern P. Food for thought in robot technology. Industry Week. 2010 May $17 ; 6: 259$.

53. Melendez K. Retail logistics: The advantages of a central distribution center [webpage on the Internet]. c2013 [updated 2013 Jul 09; cited 2016 Jul 03]. Available from: http://info.mkmdistribution.com/blog/bid/314977/RetailLogistics-The-advantages-of-a-central-distribution-center

54. McGoverin CM, Manley M. Classification of maize kernel hardness using near infrared hyperspectral imaging. J Near Infrared Spectrosc. 2012;20(5):529535. http://dx.doi.org/10.1255/jnirs.1018
55. Leatherhead Food RA. Survey: What's most important when it comes to investing in new technology [webpage on the Internet]. Cape Town: FOODStuff South Africa; 2012 [updated 2012 Sep 20; cited 2012 0ct 02]. Available from: http://foodstuffsa.co.za/news-stuff/food-science-and-technologystuff/2385-survey-whats-most-important-when-it-comes-to-investing-innew-technology

56. South African Food Review. The journal for food and beverage manufacturers [webpage on the Internet]. Cape Town: New Media Publishing; 2014 [cited 2014 0ct 06]. Available from: http://foodreview.co.za/

57. Food \& Beverage Reporter [webpage on the Internet]. c2014 [cited 2014 0ct 06]. Available from: http://www.fbreporter.co.za

58. World Bank. South Africa data [webpage on the Internet]. c2015 [cited 2015 Nov 15]. Available from: http://data.worldbank.org/country/south-africa

59. Neall B. ESL milk debuts in SA. South African Food Review. 2005;32(10):24.

60. PackagingSA. Packaging industry stats [webpage on the Internet]. c2014 [cited 2014 0ct 12]. Available from: http://www.pacsa.co.za/info-library/ packaging-industry-stats/

61. Global high barrier packaging film consumption forecast to reach 2.24 million tonnes by 2019 [webpage on the Internet]. c2014 [updated 2014 Apr 28; cited 2016 Feb 02]. Available from: http://www.smitherspira.com/ news/2014/april/high-barrier-packaging-film-consumption-forecast

62. Euromonitor International. Soft drinks in South Africa [database on the Internet]. c2013 [cited 2014 Oct 12]. Available from: http://www.portal. euromonitor.com/Portal/Default.aspx

63. Euromonitor International. Drinking milk products in South Africa [database on the Internet]. c2013 [cited 2014 0ct 12]. Available from: http://www. portal.euromonitor.com/Portal/Default.aspx

64. Euromonitor International. Yoghurt and sour milk products in South Africa [database on the Internet]. c2013 [cited 2014 0ct 12]. Available from: http:// www.portal.euromonitor.com/Portal/Default.aspx

65. Euromonitor International. Baked goods in South Africa [database on the Internet]. c2013 [cited 2014 0ct 12]. Available from: http://www.portal. euromonitor.com/Portal/Default.aspx

66. Euromonitor International. Biscuits in South Africa [database on the Internet]. c2013 [cited 2014 0ct 12]. Available from: http://www.portal.euromonitor. com/Portal/Default.aspx 